\title{
FAKTOR-FAKTOR YANG MEMPENGARUHI SENSITIVITAS LABA PADA INDUSTRI BARANG KONSUMSI DI INDONESIA
}

\author{
Candra Romanda, S.E., M.Si \\ STIE Rahmaniyah Sekayu \\ E-mail: c_romanda_mubalink@yahoo.co.id
}

\begin{abstract}
The purpose of this study was to analyze the influence of conservative financial statements, the company's life cycle, earnings growth, dividend payout ratio, default risk and size of the company's earnings response coefficients in the Consumer Goods Industry in Indonesia. The populations are 32 consumption industrial enterprises which are listed in Indonesia Stock Exchange 2007 2010. Respondent are 20 companies which were chosen by using purposive sampling. To know whether simultaneously the independent variables affect to earnings response coefficient used the $F$ test and individually the $t$ test. The results shown by the first model that conservatism did not affect the financial statements of earnings response coefficients. In addition, there were no significant differences in market response to the tendency of financial reporting either a conservative or optimistic. The company's life cycle has positive and significant impact on earnings response coefficients and earnings response coefficients are the differences between the categories of corporate life cycle. Earnings growth has positive and significant impact on earnings response coefficients. Dividend payout ratio has no effect on earnings response coefficients, Default risk has no effect on earnings response coefficients, and company size has no effect on earnings response coefficients.
\end{abstract}

Keywords: Earnings response coefficient, Financial Conservatism, Corporate Life Cycle, Income Growth, Dividend Payout Ratio, Size of the Company, Default Risk.

\section{PENDAHULUAN}

Pengumuman laba akan direspon oleh pasar, pengukuran faktor-faktor yang mempengaruhi sensitivitas laba yang diumumkan perlu dilakukan oleh seorang investor karena akan jadi bahan pertimbangan bagi investor dalam menanamkan investasinya. Secara teoritis, sensivitas laba dapat diukur dengan koefisien respon laba atau earnings respons coefficients (ERC) yaitu suatu koefisien yang berhubungan dengan informasiyang terdapat pada laba akuntansi. Koefisien inimengukur respon pasar terhadap harga saham atau nilai pasar ekuitas. Berbagai faktor determinansi dari koefisien respon laba banyak diidentifikasi oleh sejumlah penelitian akuntansi, seperti; persistensi laba, pertumbuhan, risiko dari laba, dan ukuran perusahaan (Setiati dan Kusuma, 2004: 12).
Mayangsari (2004: 155) mendefinisikan koefisien respon laba sebagai suatu dampak dari tiap dollar laba kejutan pada return saham dan biasanya diukur dengan slope koefisien hasil regresi return abnormal dan laba kejutan. Itu berarti bahwa koefisien respon laba adalah suatu reaksi yang datang dari pengumuman laba perusahaan.

Respon pasar terhadap laba masing-masing perusahaan dapat bervariasi, baik antar perusahaan maupun antar waktu. Oleh sebab itulah koefisien respon laba sering djadikan objek penelitian, terutama mengenai faktor-faktor yang mempengaruhinya, Collins dan Kothari (1989: 166) memasukkan variabel beta, persistensi laba, pertumbuhan dan size dalam pengukurannya terhadap koefisien respon laba. Mereka menemukan bahwa variabel determinan tersebut memiliki dampak penting ter- 
hadap koefisien respon laba, namun beta saham ternyata tidak berbeda secara signifikan dari nol.

Sejumlah penelitian mengenai koefisien respon laba yang telah dilakukan selama ini, berfokus pada determinan koefisien respon laba dengan mengkorelasikan laba kejutan dengan return abnormal saham (Mayangsari, 2004: 155), penelitian yang mempertimbangkan variabel siklus hidup perusahaan dalam hubungannya dengan koefisien respon laba perlu dikembangkan, sesuai dengan hasil penelitian Setiati dan Kusuma (2004: 12) menyebutkan Koefisien respon laba dalam hubungannya dengan faktor-faktor yang mempengaruhinya dapat dikembangkan dengan mempertimbangkan siklus hidup perusahaan. Karena perusahaan pada tiaptiap tahap siklus kehidupannya memiliki karakteristik yang berbeda-beda, begitu juga dengan nilai perusahaan dan growth opportunities di tiap tahapan tersebut yang tentunya menjadi pertimbangan bagi pasar untuk menanamkan modalnya. Oleh sebab itulah, muncul dugaan bahwa reaksi pasar akan terpengaruh dengan tahapan siklus hidup tersebut. Selain itu, reaksi pasar akan berbeda di tiap tahap siklus hidup perusahaan sesuai dengan Black (1998: 50) yang menyatakan bahwa siklus hidup perusahaan mempengaruhi value relevance ukuran laba dan arus kas. Perbedaan tahap siklus hidup perusahaan juga harus diperhatikan saat menghitung nilai perusahaan. National Association of Accountans menyatakan bahwa pada masing-masing tahap pertumbuhan siklus hidup perusahaan, ukuran kinerja keuangan yang berbeda mempunyai arti yang berbeda pula.

Dari uraian diatas ada beberapa hal yang menarik yang membuat penulis mengambil penelitian tentang faktor-faktor yang mempengaruhi sensitivitas laba pada industri barang konsumsi di Indonesia karena sensitivitas laba dapat mengukur respon investor terhadap pengumuman laba perusahaan, karena investor memiliki perhitungan ekspetasi laba jauh hari sebelum laporan dikeluarkan. Ambarwati (2008: 128) menyebutkan menjelang saat-saat dikeluarkannya laporan keuangan, investor lebih banyak memiliki informasi dalam membuat analisis terhadap angka laba periodik, hal ini dapat terjadi seringnya terdapat kebocoran informasi menjelang dikeluarkannya laporan keuangan. Pada waktu perusahaan mengumumkan laba tahunan, bila laba aktual lebih tinggi dibandingkan dengan hasil prediksi laba selama ini mereka buat, maka yang terjadi adalah Good News (GN), sehingga investor akan melakukan revisi ke atas terhadp laba dan kinerja perusahaan di masa yang akan datang serta memutuskan membeli saham perusahaan. Sebaliknya, jika hasil prediksi lebih tinggi dari aktualnya, yang berarti Bad News (BN), maka investor akan melakukan revisi ke bawah dan segera menjual saham perusahaan tersebut karena kinerja perusahaan tidak sesuai dengan perkiraan. Pemilihan perusahaan industri barang konsumsi dalam penelitian ini karena permintaan terhadap barang konsumsi bersifat inelastis artinya persentase perubahan jumlah barang yang diminta lebih kecil dibanding persentase perubahan harga. Permintaan terhadap barang konsumsi tidak banyak dipengaruhi oleh situasi perekonomian negara karena termasuk kebutuhan primer atau kebutuhan sehari-hari yang harus dipenuhi. Sehingga investor akan lebih tertarik menganalisis informasi laba perusahaan industri Barang konsumsi. Selain itu Industri barang konsumsi merupakan industri yang cukup diminati oleh investor karena secara keseluruhan industri barang konsumsi memiliki kapitalisasi pasar sebesar 34,31\% dari total kapitalisasi pasar Bursa Efek Indonesia selama periode 2007-2009. Hal ini menunjukkan bahwa industri barang konsumsi merupakan industri yang cukup diminati oleh investor.

Berdasarkan latar belakang yang telah dijelaskan sebelumnya, maka permasalahan penelitian ini adalah bagaimana pengaruh konservatisme laporan keuangan, siklus hidup perusahaan, pertumbuhan laba, rasio pembayaran dividen, ukuran perusahaan, dan default risk terhadap koefisien respon laba pada Industri Barang Konsumsi di Indonesia

\section{TINJAUAN PUSTAKA}

\section{Koefisien respon Laba}

Mayangsari (2004: 155) mendefinisikan koefisien respon laba sebagai suatu dampak dari tiap dollar laba kejutan pada return saham dan 
biasanya diukur dengan slope koefisien hasil regresi return abnormal dan laba kejutan. Itu berarti bahwa koefisien respon laba adalah suatu reaksi yang datang dari pengumuman laba perusahaan.

Setiati dan Kusuma (2004: 12) melakukan analisis terhadap faktor-faktor yang mempengaruhi earnings response coefficient pada perusahaan bertumbuh dan tak bertumbuh. Dalam studi mereka, variabel beta, persistensi laba, prediktabilitas laba, pertumbuhan, leverage, size, mereka uji sebagai variabel independen atas ERC. Penelitian mereka menunjukkan: (1) hasil pengujian pada perusahaan bertumbuh menunjukkan bahwa faktor persistensi laba mempengaruhi secara positifnamun faktor struktur modal mempengaruhi secara negatif terhadap koefisien respon laba, (2) hasil pengujian pada perusahaan tidak bertumbuh menunujukkan bahwa faktor persistensi laba dan size mempengaruhi secara positif namun faktor risiko beta dan struktur modal mempengaruhi secara negatif terhadap koefisien respon laba, (3) koefisien faktorfaktor yang mempengaruhi koefisien respon laba pada perusahaan bertumbuh berbeda dengan koefisien faktor-faktor yang mempengaruhi koefisien respon laba pada perusahaan tak bertumbuh.

Koefisien respon laba merupakan koefisien yang diperoleh dari regresi antara proksi harga saham dan laba akuntansi. Proksi harga saham yang digunakan adalah Cumulative Abnormal Return (CAR), Sedangkan proksi laba akuntansi yang digunakan adalah Unexpected Earnings (UE).

Cumulative Abnormal Return (CAR) pada tanggal pengumuman dihitung dengan cara sebagai berikut:

$C A R_{(t 1, t 2)}=\sum_{t 1}^{t 2} A R_{i t}$

Untuk menghitung abnormal return menurut Setiati dan Kusuma (2004: 8) adalah sebagai berikut: $A R_{i t}=R_{i t}-R_{m t}$

Dimana:

$A R_{i t}=$ abnormal return perusahaan i pada harit

$R_{i t}=$ return sesungguhnya perusahaan i pada harit

$R_{m t}=$ return pasar pada hari $\mathrm{t}$
Return sesungguhnya dihitung dengan cara sebagai berikut:

$R_{i t}=\frac{P_{i t}-P_{i t-1}}{P_{i t-1}}$

Dimana:

$R_{i t}=$ return sesungguhnya perusahaan i pada harit

$P_{i t}=$ harga penutupan sahami pada hari $\mathrm{t}$

$P_{i t-1}=$ harga penutupan saham i pada hari t-1

Return pasar dihitung dengan cara sebagai berikut:

$R_{m t}=\frac{I H S G_{t}-I H S G_{t-1}}{I H S G_{t-1}}$

Dimana:

$R_{m t} \quad=$ return pasar pada hari $\mathrm{t}$

$I H S G_{t}=$ indeks harga saham gabungan pada harit

$\begin{aligned} I H S G_{t-1} & =\text { indeks harga saham gabungan pada } \\ \text { hari t-1 } & \end{aligned}$

Persamaan untuk menghitung UE sesuai dengan penelitian Febrianto dan Widiastuty (2005: 165). Secara matematis persamaan tersebut:

$$
U E_{i t}=\frac{\left(E P S_{i t}-E P S_{i t-1}\right)}{P_{i t-1}}
$$

Dimana:

$$
\begin{aligned}
U E_{i t}= & \text { unexpected earnings perusahaan } \mathrm{i} \\
& \text { pada periode } \mathrm{t} \\
E P S_{i t}= & \text { earnings per share perusahaan i pada } \\
& \text { periode } \mathrm{t} \\
E P S_{i t-1}= & \text { earnings per share perusahaan i pada } \\
& \text { periode } \mathrm{t}-1 \\
P_{i t-1}= & \text { harga saham (closing price) perusa- } \\
& \text { haan i pada periode } \mathrm{t}-1
\end{aligned}
$$

ERC merupakan variabel dependen pada penelitian ini yang dihitung dengan slope á1 pada hubungan CAR dengan UE yaitu:

$$
\mathrm{CAR}_{\mathrm{it}}=\alpha_{0}+\alpha_{1} \mathrm{UE}_{\mathrm{it}}+\alpha_{2} \mathrm{R}_{\mathrm{it}}+\varepsilon_{\mathrm{it}}
$$

Dimana:

$$
\begin{aligned}
\mathrm{CAR}_{\mathrm{it}}= & \text { abnormal return kumulatif perusahaan } \\
& \text { i selama perioda amatan } \underline{+-} 5 \text { hari dari } \\
& \text { publikasi laporan keuangan }
\end{aligned}
$$




$$
\begin{aligned}
\mathrm{UE}_{\mathrm{it}}= & \text { unexpected earnings } \\
\varepsilon_{\mathrm{it}} & =\text { komponen error dalam model atas } \\
& \text { perusahaan i pada periodat }
\end{aligned}
$$

\section{Konservatisme Laporan Keuangan}

Konservatisme merupakan salah satu prinsip penting dalam pelaporan keuangan yang dimaksudkan agar pengakuan dan pengukuran aktiva serta laba dilakukan dengan penuh kehati-hatian oleh karena aktivitas ekonomi dan bisnis dilingkupi ketidakpastian. Oleh sebab itulah seringkali konservatisme dianggap sebagai prinsip akuntansi yang kontroversial. Implikasinya pada laporan keuangan umumnya yaitu akan segera mengakui biaya atau rugi yang kemungkinan besar akan terjadi tetapi tidak mengantisipasi (mengakui lebih dulu) untung atau pendapatan yang akan datang walaupun kemungkinan terjadinya besar (Suwardjono, 2005: 245).

Penelitian mengenai hubungan antara konservatime dan reaksi pasar ini juga dilakukan oleh Dewi (2004: 221) yang menghubungkan konservatisme dengan koefisien respon laba. Hasil penelitian tersebut menunjukkan: (1) terdapat gabungan yang signifikan antara konservatime laporan keuangan dengan discretionary accruals, (2) koefisien respon laba pada laporan keuangan yang persisten dan optimis berbeda dengan laporan keuangan konservatif dan persisten, (3) koefisien respon laba pada laporan keuangan optimis lebih tinggi bila dibandingkan dengan laporan keuangan yang konservatif. konservatisme sesuai dengan proksi dalampenelitian yang digunakan oleh Dewi(2004:214).

$$
\mathrm{C}_{\mathrm{it}}=\mathrm{NI}_{\mathrm{it}}-\mathrm{CF}_{\mathrm{it}}
$$

Dimana:

$\mathrm{C}_{\mathrm{it}}=$ tingkat konservatisma

$\mathrm{NI}_{\mathrm{it}}=$ net income sebelum extraordinary item dikurangi depresiasi dan amortisasi

$\mathrm{CF}_{\mathrm{it}}=$ cash flow dari kegiatan operasional.

\section{Siklus Hidup Perusahaan}

Hingga kini tidak terdapat konsensus atas definisi baku dari siklus hidup perusahaan. Terdapat beberapa model tahapan siklus kehidupan perusahaan yang sering digunakan; five-stage models, four-stage models dan three-stage models. Tiap model tersebut didukung oleh sejumlah literatur mengenai siklus hidup perusahaan (Quinn dan Cameron, 1983) dalam Yan (2006: 1).

Menurut Gup danAggarwal(1996: 42) setiap perusahaan pasti mengalami tahapan siklus kehidupan di mana siklus ini identik dengan siklus kehidupan perusahaan. Adapun tahap dari siklus kehidupan perusahaan adalah tahap pendirian (start up), tahap ekspansi (expansion), tahap kedewasaan (mature), dan tahap penurunan (declining). Penetapan siklus kehidupan perusahaan dalam Gup dan Agrrawal (1996: 44) didasarkan pada pertumbuhan penjualan yang dihitung dengan rumus:

NetSalesAverage $=\frac{\left(\text { net sales } t-\text { net }_{\text {sales }} \text { s-1 }_{1}\right)}{\text { net } \text { sales }_{t-1}} \times 100 \%$

Setelah pertumbuhan penjualan diketahui dari rumus tersebut, maka perusahaan-perusahaan yang menjadi sampel penelitian dikelompokkan pertumbuhan penjualan ke dalam tiap-tiap siklus kehidupan dengan mengikuti kriteria seperti Gup dan Aggarwal (1996: 44) sebagai berikut:

Tabel Kriteria Average Sales Growth

\begin{tabular}{ccc}
\hline Tahapan & $\begin{array}{c}\text { Rata-Rata } \\
\text { Pertumbuhan Penjualan } \\
\text { Selama 5 Tahun }\end{array}$ & $\begin{array}{c}\text { Nomor } \\
\text { Kriteria }\end{array}$ \\
\hline Start Up & $>50 \%$ & 1 \\
Ekspansi Awal & $20-49,9 \%$ & 2 \\
Ekspansi Akhir & $10-19,9 \%$ & 3 \\
Mature & $0-9,9 \%$ & 4 \\
Decline & $<0 \%$ & 5 \\
\hline
\end{tabular}

\section{Pertumbuhan Laba}

Pertumbuhan laba adalah variabel yang menjelaskan prospek pertumbuhan di masa mendatang. Pertumbuhan laba diprediksikan berhubungan positif dengan koefisien respon laba (Collins dan Kothari, 1989; Martikainen, 1997; Bae dan Sami, 1999; dalam Widiastuti, 2002). Collins dan Kothari (1989), Bae dan Sami (1999) dalam Mayangsari (2004: 157) menunjukkan bahwa perusahaan yang memiliki kesempatan tumbuh yang lebih besar akan memiliki koefisien respon laba yang tinggi. Kondisi 
tersebut menunjukkan bahwa semakin besar kesempatan bertumbuh perusahaan maka semakin tinggi kesempatan perusahaan mendapatkan laba yang diperoleh perusahaan pada masa mendatang.

Pertumbuhan diukur sesuai rumusan yang digunakan oleh Collins dan Kothari (1989) dalam Setiati dan Kusuma (2004: 9), Bae dan Sami (1999) dalam Mayangsari (2004), yaitu dengan market to book ratio.

Market - to - book ratio $=\frac{\text { Market capitalization }}{\text { Book value of equity }}$

\section{Rasio Pembayaran Dividen}

Pengumuman pembagian dividen oleh suatu perusahaan merupakan sinyal bagi pemegang saham. Pada dasarnya antara manajer dengan pemegang saham memiliki informasi yang berbeda dimana manajer lebih memiliki informasi yang lengkap daripada pemegang saham. Pemegang saham akan menginterpretasikan peningkatan pembayaran dividen oleh perusahaan, sebagai sinyal bahwa pihak manajemen memiliki prediksi arus kas yang tinggi dimasa yang akan datang (Murhadi, 2008: 2).

Charest (1978) dalam Uyara dan Tuasikal (2003: 187) menunjukkan bahwa return saham negatif ketika perusahaan mengurangi dividen dan return saham positif pada saat perusahaan menaikkan dividen. Amihud dan Li (2002: 31) menemukan bahwa sejak pertengahan 1970, terjadi penurunan reaksi harga saham terhadap pengumuman perubahan dividen, baik pada abnormal returns saham dan perubahan di sekitar pengumuman.

Uyara dan Tuasikal(2003: 196) menghubungkan rasio pembayaran dividen dengan koefisien respon laba. Penelitian tersebut menunjukkan bahwa hubungan rasio pembayaran dividen dan earnings response coefficient berbanding lurus namun tidak signifikan secara statistik. Akan tetapi setelah rasio pembayaran dividen dan earnings response coefficient diregresi dengan memasukkan aliran kas bebas sebagai variabel moderasi, hubungannya menjadi signifikan secara statistik.

Penggunaan proksi rasio pembayaran dividen ini sesuai dengan penelitian Uyara dan Tuasikal
(2003: 191). Variabel ini diformulasikan sebagai berikut:

$$
\text { Rasio Pembayaran Dividen }=\frac{\text { Dividend }}{\text { Net Income }}
$$

\section{Ukuran Perusahaan}

Ukuran perusahaan merupakan salah satu karakteristik perusahaan. Variabel ini sering digunakan dalam berbagai penelitian yang berhubungan dengan koefisien respon laba sebagai variabel kontrol. Besaran perusahaan sebenarnya merupakan proksi dari keinformatifan harga. Perusahaan besar dianggap memiliki informasi yang lebih banyak dibandingkan perusahaan kecil. Konsekuensinya, semakin informatif harga saham maka semakin kecil pula muatan informasi current earnings (Mayangsari, 2004: 159).

Setiati dan Kusuma (2004: 12) dalam penelitiannya menunjukkan bahwa ukuran perusahaan memiliki pengaruh positif signifikan terhadap koefisien respon laba pada perusahaan tidak bertumbuh, dan tidak berpengaruh pada perusahaan bertumbuh. Mayangsari (2004: 172) ukuran perusahaan dalam penelitiannya digunakan sebagai variabel kontrol dan hasilnya menunjukkan bahwa ukuran perusahaan berpengaruh signifikan terhadap ERC. Pada perusahaan dalam keadaan merugi, perusahaan besar lebih mendapat perhatian investor dibandingkan dengan perusahaan kecil. Naimah dan Utama (2006:18) pada penelitiannya ERC pada perusahaan besar ternyata memiliki koefisien yang lebih besar dibandingkan dengan perusahaan kecil. Hasil tersebut sesuai dengan penelitian terdahulu Chaney dan Jater (1992), Easton dan Zmijewski (1989) yang menemukan hubungan positif antara ukuran perusahaan dan ERC.

Dalam penelitian ini ukuran perusahaan diproksikan dengan natural log dari total aset. Ini sesuai dengan penelitian yang dilakukan oleh Setiati dan Kusuma (2004: 11)

\section{Default Risk}

Papanastasopoulos (2006: 1) mendefinisikan default risk sebagai suatu ketidakpastian yang 
berhubungan dengan kemampuan perusahaan untuk memenuhi kewajiban atau contractual obligations-nya. Beberapa dekade terakhir, default risk berkembang signifikan sebagai topik dalam penelitian keuangan dan akuntansi. Pada proksi pengukurannya, terdapat dua kategoriutama dalam default risk model; credit scoring models dan structural models. Credit scoring models dikembangkan oleh Beaver (1966), Altman (1967, 1975), Ohlson (1980) dan Zmijewski (1984) dan mengadopsi pendekatan tradisional. Dalam pendekatan trandisional tersebut, identifikasi dilakukan terhadap sejumlah kondisi keuangan perusahaan seperti; size, likuiditas, leverage, profitabilitas, efisiensi dan kecukupan arus kas. Pada model ini informasi akuntansi dan teknik statistik digunakan untuk mengukur default risk suatu perusahaan. Sedangkan structural models, model yang dikembangkan oleh Black dan Scholes (1973) dan Merton (1974) ini, mengadopsi the option approach. Di mana informasi pasar dan option pricing techniques digunakan untuk menilai default risk suatu perusahaan.

Default risk pada penelitian ini diproksikan dengan leverage. Proksi leverage ini. sesuai dengan penelitian, Setiati dan Kusuma (2004). Variabel ini diformulasikan sebagai berikut:

$$
\text { Leverage }=\frac{\text { Total Utang }}{\text { Total Aktiva }}
$$

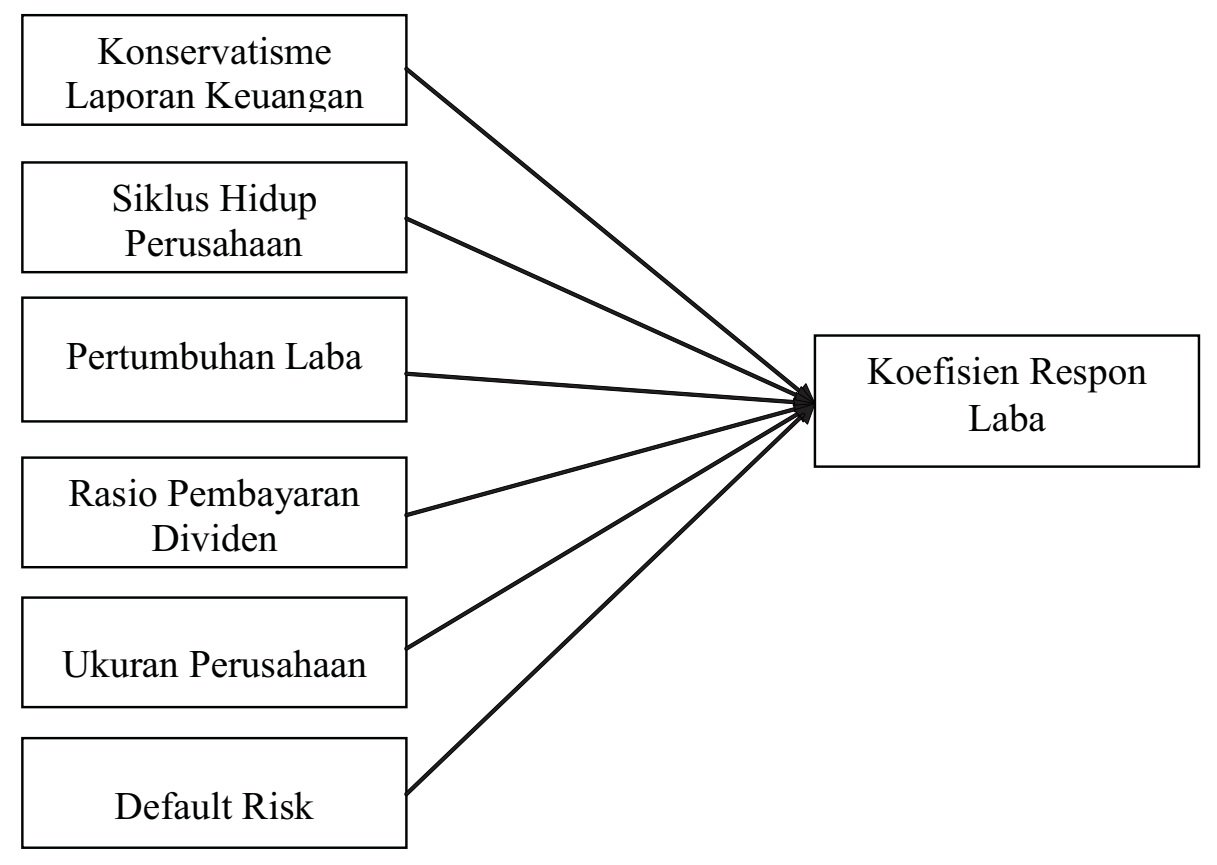

\section{Hipotesis Penelitian}

Berdasarkan gambar kerangka pimikiran, maka disusun hipotesis sebagai berikut:

$\mathrm{H}_{1}$ : Terdapat pengaruh antara konservatisme laporan keuangan dengan koefisien respon laba.

$\mathrm{H}_{2}$ : Siklus hidup perusahaan berpengaruh terhadap koefisien respon laba.

$\mathrm{H}_{3}$ : Pertumbuhan laba perusahaan berpengaruh terhadap koefisien respon laba.

$\mathrm{H}_{4}$ : Rasio pembayaran dividen berpengaruh terhadap koefisien respon laba.
$\mathrm{H}_{5}$ : Ukuran perusahaan berpengaruh terhadap koefisien respon laba.

$\mathrm{H}_{6}$ : Default Risk berpengaruh terhadap koefisien respon laba.

\section{METODE PENELITIAN}

\section{Ruang Lingkup Penelitian}

Penelitian ini mengambil populasi dari seluruh perusahaan industri barang konsumsi yang sudah 
go public yang terdaftar di Bursa Efek Indonesia periode 2007-2010. Jumlah seluruh perusahaan industri barang konsumsi adalah 32 perusahaan (terlampir).

Pemilihan sampel dalam penelitian ini menggunakan metode purposive sampling. Purposive sampling merupakan desain pengambilan sampel yang memenuhi kriteria yang ditentukan oleh peneliti. Kriteria pemilihan sampel yang ditentukan adalah sebagai berikut:

1. Perusahaan Industri Barang Konsumsi yang terdaftar di BEI periode tahun 2007-2010.

2. Perusahaan yang sahamnya masih aktif diperdagangkan selama tahun 2007-2010 dan tidak delisting selama tahun penelitian tersebut.

3. Perusahaan yang memiliki laporan keuangan tahunan yang berakhir pada tanggal 31 Desember.

4. Perusahaan yang mengeluarkan dividend selama periode penelitian.

Berdasarkan kriteria yang telah ditetapkan penulis di atas, maka terdapat 20 perusahaan industri konsumsi yang dapat dijadikan sample dalam penelitian ini. Tabel III.1 di bawah ini menunjukkan proses pemilihan sampel penelitia.

Tabel Pemilihan Sampel

\begin{tabular}{lc}
\hline \multicolumn{1}{c}{ Keterangan } & Jumlah Perusahaan \\
\hline $\begin{array}{l}\text { Perusahaan Industri Konsumsi yang terdaftar tahun } 2007-2010 \\
\text { Perusahaan Industri Konsumsi yang tidak memenuhi kriteria (tidak mengeluarkan } \\
\text { dividen pada periode penelitian) }\end{array}$ & $\mathbf{3 2}$ \\
Jumlah Perusahaan manufaktur yang dijadikan sampel & $\mathbf{2 0}$ \\
\hline
\end{tabular}

\section{Jenis dan Sumber Data}

Jenis data yang digunakan dalam penelitian ini adalah data sekunder berupa laporan keuangan 2007-2010. Data tersebut diperoleh dari situs BEI, yaitu www.idx.co.id, IDX statistics 2007-2010, IDX Fact Book 2007-2010, situs finance.yahoo. com dan Indonesian Capital Market Directory (ICMD).

\section{Metode Pengumpulan Data}

Data dikumpulkan dengan menggunakan metode studi pustaka dan dokumentasi. Studi pustaka dilakukan dengan menggunakan literatur, artikel, jurnal maupun media tertulis lain yang berkaitan dengan topik pembahasan dari penelitian ini. Dokumentasi dilakukan dengan mengumpulkan sumber-sumber data dokumenter seperti laporan keuangan perusahaan yang menjadi sampel penelitian.

\section{HASIL PENELITIAN DAN PEMBAHASAN}

Dari data masing - masing sampel yang dijadikan bahan analisis bagi penulis untuk mengetahui pengaruh konservatisme laporan keuangan, siklus hidup perusahaan, pertumbuhan laba, rasio pembayaran dividen, ukuran perusahaan dan default risk terhadap koefisien respon laba pada industri barang konsumsi.

Analisis data berupa analisis penelitian yang membahas tentang statistik deskriptif, uji asumsi klasik, uji hipotesis serta pembahasan hasil penelitian dan uji regresi. Analisis data pada penelitian ini dilakukan menggunakan program SPSS for windows versi 15.0

\section{Statistik Deskriptif}

Pengujian ini dimaksudkan untuk memberikan gambaran atau deskripsi suatu data yang dilihat 
dari minimum, maksimum, mean, dan standar deviasi dari masing-masing sampel. Berikut ini adalah statistik deskriptif data dari sampel penelitian:

Descriptive Statistics

\begin{tabular}{|l|r|r|r|r|r|}
\hline & \multicolumn{1}{|c|}{$\mathrm{N}$} & \multicolumn{1}{|c|}{ Minimum } & Maximum & \multicolumn{1}{c|}{ Mean } & Std. Deviation \\
\hline ERC & 20 &, 0003 &, 7469 &, 249916 &, 2568033 \\
ACC & 20 &,- 6020 &, 1141 &,- 029890 &, 1431479 \\
FLC & 20 & 2,00 & 4,00 & 2,9500 &, 60481 \\
GROWTH & 20 &, 0400 & 3,1357 &, 951935 &, 8167832 \\
DPR & 20 &, 0017 & 1,2000 &, 406295 &, 3848148 \\
SIZE & 20 & 25,1558 & 34,9511 & 28,451810 & 2,2483398 \\
LEV & 20 &, 0959 &, 6744 &, 358352 &, 1759977 \\
Valid N (listwise) & 20 & & & & \\
\hline
\end{tabular}

Sumber: Data sekunder yang diolah

\section{Uji Asumsi Klasik}

\section{Uji Normalitas Data}

Normalitas data diuji dengan menggunakan kolmogorov-smirnov dengan level of significant 0,05 . Berikut ini adalah data hasil uji normalitas.
Dari tabel diatas terlihat pengujian kolmogorovsmirnov yang telah dilakukan, semua variabel, baik ERC, ACC, FLC, GRWTH, DPR, SIZE, dan LEV yang akan digunakan dalammodel penelitian memiliki p-value lebih besar dari level of significant sebesar 0.05. Maka dapat diambil kesimpulan bahwa semua variabel berdistribusi normal.

\begin{tabular}{|c|c|c|c|c|c|c|c|c|}
\hline \multicolumn{9}{|c|}{ One-Sample Kolmogorov-Smirnov Test } \\
\hline & & ERC & $\mathrm{ACC}$ & FLC & GROWTH & DPR & SIZE & LEV \\
\hline $\mathrm{N}$ & & 20 & 20 & 20 & 20 & 20 & 20 & 20 \\
\hline \multirow{2}{*}{ Normal Parameters $a, b$} & Mean & 249916 &,- 029890 & 2,9500 & ,951935 & 406295 & 28,451810 & ,358352 \\
\hline & Std. Deviation & ,2568033 & , 1431479 & ,60481 & ,8167832 & ,3848148 & 2,2483398 & ,1759977 \\
\hline \multirow{3}{*}{$\begin{array}{l}\text { Most Extreme } \\
\text { Differences }\end{array}$} & Absolute & , 254 & ,363 & ,333 & 199 & 174 & 158 & 186 \\
\hline & Positive & ,254 & 174 & ,317 & 199 & 174 & 158 & 186 \\
\hline & Negative &,- 166 &,- 363 &,- 333 &,- 132 &,- 147 &,- 129 &,- 145 \\
\hline Kolmogorov-Smirnov Z & & 1,138 & 1,623 & 1,489 & ,889 & ,780 & ,706 & ,833 \\
\hline Asymp. Sig. (2-tailed) & & 150 &, 010 &, 024 & ,408 &, 577 & ,701 & ,492 \\
\hline
\end{tabular}

a. Test distribution is Normal.

b. Calculated from data.

\section{Uji Multikolinearitas}

Uji multikolinearitas bertujuan untuk menguji apakah terdapat korelasi antar variabel independen dalam model regresi (Ghozali, 2006: 46). Model regresi yang baik seharusnya bebas dari multikolinearitas, berikut ini hasi Uji Multikolinearitas dengan menggunakan program SPSS for windows versi 15.0:

\section{Uji Multikolinearitas}

Multikolinearitas dapat dilihat dari nilai Tolerance dan Variance Inflation Factor Factor $(V I F)$. Hasil uji multikolinearitas dapat dilihat pada Tabel diatas Hasil uji multikolinearitas menunjukkan bahwa tidak ada variable yang memiliki nilai tolerance kurang dari $10 \%$ dan tidak ada variable yang memiliki VIP lebih dari 10. Sehingga dapat disimpulkan bahwa model regresi dapat digunakan karena tidak terjadi multikolinearitas di dalamnya. 


\section{Coefficients $^{\mathrm{a}}$}

\begin{tabular}{|c|c|c|c|c|c|c|c|c|}
\hline \multirow{2}{*}{\multicolumn{2}{|c|}{ Model }} & \multicolumn{2}{|c|}{$\begin{array}{c}\text { Unstandardized } \\
\text { Coefficients }\end{array}$} & \multirow{2}{*}{$\begin{array}{c}\begin{array}{c}\text { Standardized } \\
\text { Coefficients }\end{array} \\
\text { Beta }\end{array}$} & \multirow[b]{2}{*}{$\mathrm{t}$} & \multirow[b]{2}{*}{ Sig. } & \multicolumn{2}{|c|}{ Collinearity Statistics } \\
\hline & & B & Std. Error & & & & Tolerance & VIF \\
\hline \multirow[t]{7}{*}{1} & (Constant) &,- 256 & ,714 & &,- 358 & ,726 & & \\
\hline & $\mathrm{ACC}$ & ,204 & ,414 & ,114 & ,493 & ,630 & ,748 & 1,337 \\
\hline & FLC & ,209 & ,097 & , 493 & 2,149 & 051 & ,755 & 1,324 \\
\hline & GROWTH & , 142 &, 066 & ,451 & 2,142 & 052 & , 897 & 1,115 \\
\hline & DPR &,- 178 & ,146 &,- 267 & $-1,218$ & ,245 & , 829 & 1,207 \\
\hline & SIZE &,- 012 & 026 &,- 104 &,- 468 & ,648 & ,798 & 1,253 \\
\hline & LEV & , 477 & ,375 & , 327 & 1,273 & ,225 & ,604 & 1,656 \\
\hline
\end{tabular}

a. Dependent Variable: ERC

\section{Uji Autokorelasi}

Uji autokorelasi dari20 sampel penelitian menunjukkan bahwa nilai dari Durbin-Watson menunjukkan 2,061, hasil tersebut menyatakan bahwa tidak ada keputusan apakah terjadi atau tidak terjadi autokorelasi hal ini dapat dilihat pada
Ghozali (2006;96) dimana posisi $\mathrm{dl}<\mathrm{d} \leq \mathrm{du}$, berdasarkan tabel Durbin-Watson diketahui bahwa $\mathrm{dl}=0,692 \mathrm{dan} \mathrm{du}=2,162$ dari nilai ini berarti bahwa d-hitung berada pada daerah keragu-raguan. Oleh karena d-hitung lebih condong mendekati bebas autokorelasi maka dengan demikian dianggap tidak ada autokorelasi.

Model Summary ${ }^{\mathrm{b}}$

\begin{tabular}{|l|r|r|r|r|r|}
\hline Model & $\mathrm{R}$ & R Square & $\begin{array}{c}\text { Adjusted } \\
\text { R Square }\end{array}$ & $\begin{array}{c}\text { Std. Error of } \\
\text { the Estimate }\end{array}$ & $\begin{array}{c}\text { Durbin- } \\
\text { Watson }\end{array}$ \\
\hline 1 &, $695^{\mathrm{a}}$ &, 483 &, 244 &, 2232664 & 2,061 \\
\hline
\end{tabular}

a. Predictors: (Constant), SIZE, FLC, ACC, GROWTH, DPR, LEV

b. Dependent Variable: ERC

\section{Uji Heteroskedastisitas}

Pada Grafik scatterplot yang dihasilkan dari pengujian heteroskedastisitas di atas, menunjukkan bahwa tidak terdapat pola tertentu, titik-titik menyebar secara acak di atas dan dibawah angka nol pada sumbu Y. Maka dapat disimpulkan bahwa tidak terjadi heteroskedastisitas pada model regresi ini.

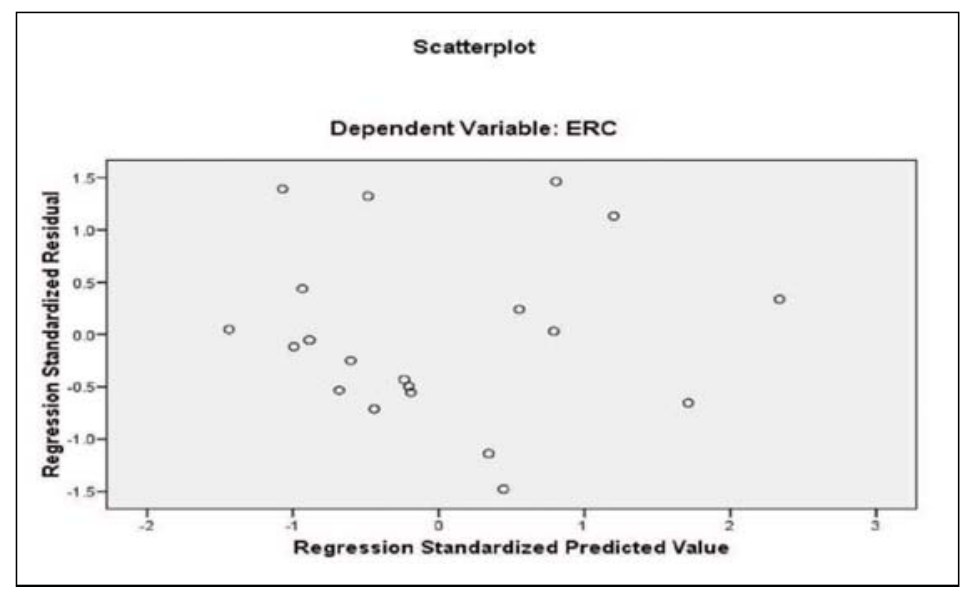

Sumber: data sekunder yang diolah 


\section{Uji Hipotesis}

\section{Koefisien Determinasi}

Besarnya $\mathrm{R}^{2}$ dalam yaitu 0,483 hal ini berarti $48 \%$ variasi earning respons coefficient dapat dijelaskan oleh variasi dari variable accrual, FLC, growth, DPR, size, dan leverage. Sedang sisanya sebesar 52\% dijelaskan oleh sebab-sebab lain di luar model.

\begin{tabular}{|l|r|r|r|r|r|}
\multicolumn{7}{|c|}{ Model Summary $^{\circ}$} \\
\hline Model & \multicolumn{1}{|c|}{ R } & R Square & $\begin{array}{c}\text { Adjusted } \\
\text { R Square }\end{array}$ & $\begin{array}{c}\text { Std. Error of } \\
\text { the Estimate }\end{array}$ & $\begin{array}{c}\text { Durbin- } \\
\text { Watson }\end{array}$ \\
\hline 1 &, $695^{\text {a }}$ &, 483 &, 244 &, 2232664 & 2,061 \\
\hline
\end{tabular}

a. Predictors: (Constant), SIZE, FLC, ACC, GROWTH, DPR, LEV

b. Dependent Variable: ERC

\section{Uji Statistik F}

Uji F digunakan untuk menguji Pengaruh secara simultan atau secara bersama-sama variabel independen terhadap Varibel Dependen
Dari Tabel di atas $\mathrm{F}_{\text {hitung }}$ 2,032 dengan $p$-value 0,135 yang berarti lebih besar dari 0,05 maka dapat dikatakan bahwa vaiabel accrual, FLC, growth, DPR, size, dan leverage secara simultan atau bersama-sama tidak berpengaruh terhadap earnings respons coefficient pada level of significant $5 \%$.

ANOVA $^{b}$

\begin{tabular}{|ll|r|r|r|r|r|}
\hline Model & & $\begin{array}{c}\text { Sum of } \\
\text { Squares }\end{array}$ & df & Mean Square & F & Sig. \\
\hline 1 & Regression &, 605 & 6 &, 101 & 2,023 &, $135^{\mathrm{a}}$ \\
& Residual &, 648 & 13 &, 050 & & \\
& Total & 1,253 & 19 & & & \\
\hline
\end{tabular}

a. Predictors: (Constant), SIZE, FLC, ACC, GROWTH, DPR, LEV

b. Dependent Variable: ERC

\section{Uji Statistik t}

Ujit digunakan untuk mengetahui pengaruh variabel independen terhadap variabel dependen secara parsial denganpersamaan regresi sebagai berikut:

$$
\begin{aligned}
\mathrm{ERC}= & -0,256+0,204 \mathrm{ACC}+0,209 \mathrm{FLC}+ \\
& 0,142 \mathrm{GRWTH}-0,178 \mathrm{DPR}-0,012 \mathrm{SIZE} \\
& +0,477 \mathrm{LEV}+\varepsilon_{\mathrm{it}}
\end{aligned}
$$

\begin{tabular}{|c|c|c|c|c|c|c|}
\hline \multirow[b]{2}{*}{ Mod } & & \multicolumn{2}{|c|}{$\begin{array}{l}\text { Unstandardized } \\
\text { Coefficients }\end{array}$} & \multirow{2}{*}{$\begin{array}{c}\text { Standardized } \\
\text { Coefficients }\end{array}$} & \multirow[b]{2}{*}{$\mathrm{t}$} & \multirow[b]{2}{*}{ Sig. } \\
\hline & & B & Std. Error & & & \\
\hline \multirow[t]{7}{*}{1} & (Constant) &,- 256 & ,714 & &,- 358 &, 726 \\
\hline & ACC & 204 & 414 & 114 & 493 & ,630 \\
\hline & FLC & 209 & , 097, & 493 & 2,149 & ,051 \\
\hline & GROWTH & 142 & , 066 & 451 & 2,142 & ,052 \\
\hline & DPR & - 178 & 146 &,- 267 & $-1,218$ & 245 \\
\hline & SIZE &,- 012 & , 026 &,- 104 &,- 468 & 648 \\
\hline & LEV & ,477 & ,375 & ,327 & 1,273 & ,225 \\
\hline
\end{tabular}

\section{Coefficients $^{\mathrm{a}}$}

a. Dependent Variable: ERC 
Dari Tabel diatas diketahui Konservatisme laporan keuangan (ACC) sebesar 0,493 dan nilai probabilitas $0,630>$ taraf signifikansi $5 \%$, artinya tidak ada pengaruh antara konservatisme laporan keuangan terhadap koefisien respon laba. Hal ini menunjukkan bahwa pelaku pasar industri barang konsumsi yang sudah berinvestasi pada bursa efek Indonesia tidak terlalu memperdulikan prinsifkonservatisme dari laporan keuangan perusahaan, walaupun sikap konservatif merupakan sikap berhati-hati dalam menghadapi risiko dengan cara segera mengakui biaya atau rugi serta tidak mengakui terlebih dahulu pendapatan atau untung walaupun kemungkinan terjadinya besar (suwardjono, 2005:245). Para investor seharusnya perlu mempertimbangkan lagipenerapan prinsif konservatisme dari laporan keuangan perusahaan karena prinsif tersebut dapat lebih menunjukkan nilai real dari angka - angka yang terdapat dalam laporan keuangan yang bisa direalisasikan, dan sikap hatihati dalam mengakui angka-angka dalam laporan keuangan lebih menjamin uang yang ditanamkan tidak mengalami penyalahgunaan dan rekayasa laporan oleh pihak manajemen yang mengelola perusahaan.

Pengujian hipotesis kedua tentang pengaruh siklus hidup perusahaan ditemukan t hitung sebesar 2,149 dan nilai probabilitas 0,051 dengan taraf signifikansi 5\%, artinya bahwa ada pengaruh positif dan signifikan antara siklus hidup perusahaan terhadap koefisien respon laba. Hasil Penelitan ini menunjukkan bahwa siklus hidup perusahaan yang memiliki kecenderungan respon positif dan meningkatkan koefisien respon laba karena para investor sangat antusias untuk menanamkan dananya pada perusahaan yang mengalami tingkat penjualan yang lebih tinggi, dan pengukuran siklus hidup perusahaan dalam penelitian ini sesuai dengan penelitian Gup dan Aggarwal (1996) dan penelitian Juniarti dan Limanjaya (2005) yaitu dengan cara mengukur pertumbuhan penjualan masing-masing perusahaan. Selain itu kamungkinan respon positif dari pelaku pasar pada industri barang konsumsi Indonesia karena produk yang dihasilkan konsumennya adalah masyarakat umum, sehingga tingkat penjualan merupakan tolak ukur kinerja per- usahaan, yang secara tidak langsung berdampak pada koefisen respon laba perusahaan. Bagi pemerintah sangat penting memberikan support kepada industri barang konsumsi karena industri barang konsumsi, mampu menopang perekonomian Negara karena produk yang dihasilkan dan dijual langsung berhubungan dengan kehidupan rakyat Indonesia. Dan untuk Bapepam sebagai pengawas pasar modal di Indonesia perlu mempertimbangkan untuk terus mengawasi Industri barang konsumsi bukan hanya tingkat penjualan tapi juga dari aspek lain misalnya produk perusahaan industri konsumsi juga harus mempertimbangkan dampak terhadap kesehatan masyarakat, sehingga industri barang konsumsi yang hanya mengejar tingkat penjualan atau keuntungan, tetapi manfaat produk bagi masyarakat.

Pengujian terhadap pengaruh pertumbuhan laba terhadap koefisien respon laba didapat nilait hitung sebesar 2,142 dan nilai probabilitas 0,052 dengan taraf signifikansi 5\%, artinya bahwa ada pengaruh positif dan signifikan Pertumbuhan Laba terhadap koefisien respon laba. Dari hasil penelitian ini menunjukkan bahwa kenaikan pertumbuhan laba akan meningkatkan koefisien respon laba, hal ini menggambarkan bahwa investor sangat merespon kondisi pertumbuhan laba perusahaan dan sesuai dengan penelitian naimah (2005) yang menyatakan bahwa pada perusahaan yang mengalami pertumbuhan tinggi, pengaruh laba dan harga saham akan lebih besar dibandingkan dengan perusahaan yang mengalami pertumbuhan rendah. Pertumbuhan laba merupakan faktor yang berpengaruh terhadap koefisien respon laba karena jika pertumbuhan laba naik maka respon pasar juga akan naik sesuai dengan yang disampaikan oleh Ambarwati (2008: 128).

Jika pertumbuhan laba naik maka merupakan Good News sehinggan investor akan merespon secara positif dan melakukan keputusan membeli saham perusahaan. Para investor perlu melakukan analisis dan mempertimbangkan untuk melakukan pembelian saham pada perusahaan yang cenderung pertumbuhan laba meningkat, karena mengindikasikan kinerja perusahaan semakin baik, sehingga investasi yang ditanamkan tetap aman, selain in- 
vestor pihak pemerintah juga harus merespon secara positif terhadap perusahaan yang memiliki pertumbuhan laba yang cenderung meningkat karena akan menunjang dan memastikan pajak dari laba akan meningkat, dan Badan pengawas pasar modal harus merespon industri-industri yang memiliki kinerja laba ataupun pertumbuhan laba yang cenderung meningkat agar diberi penghargaan (reward) yang berdampak secara tidak langsung terhadap penilaian masyarakat terhadap penilaian atau persepsi masyarakat terhadap perusahaan yang mendapat penghargaan tersebut.

Pengujian terhadap pengaruh rasio pembayaran Dividen terhadap koefisien respon laba ketahui nilai t hitung sebesar -1,218 dan nilai probabilitas $0,245>$ taraf signifikansi $5 \%$, artinya artinya bahwa tidak ada pengaruh antara rasio pembayaran divien terhadap koefisien respon laba dan didapat hasil angka negatif hal ini bertolak belakang dengan penelitian-penelitian sebelumnya yang dilakukan oleh Amihud dan Li(2002), Uyara dan Tausikal (2003), Murhadi(2008). Respon negatif rasio pembayaran dividen ini kemungkinan disebabkan investor tidak terlalu perduli dengan tingkat pembayaran dividen terutama pada periode 2007 - 2010 karena kondisi perekonomian dunia yang sedang mengalami krisis pada tahun 2008 yang juga mempengaruhi kondisi perekonomian pada industribarang konsumsi, hal ini diketahui karena industri barang konsumsi banyak yang tidak membagikan dividen, sehingga investor lebih merespon tingkat penjualan perusahaan dan tingkat pertumbuhan laba. Para pelaku pasar pada perusahaan industri konsumsi kalau mau membeli saham perusahaan pada industri barang konsumsi dengan tujuan untuk memperoleh dividen harus berhati-hati karena investasi yang ditanamkan butuh waktu yang lama untuk mendapatkan dividen dan rasio pembayaran dividen direspon negativ oleh pasar karena perusahaan lebih fokus kepada tingkat penjualan, tetapi investasi sangat bagus jika tujuan investor berinvestasi untuk memperoleh hak suara.

Pengujian terhadap pengaruh ukuran perusahaan (size) terhadap Koefisien Respon Labavdi atas didapat nilait hitung sebesar -0,468 dan nilai probabilitas $0,648>$ taraf signifikansi 5\% artinya bahwa tidak ada pengaruh ukuran perusahaan terhadap koefisien respon laba. Hasil penelitian ini menunjukkan bahwa tinggi rendahnya ukuran perusahaan tidak berpengaruh terhadap kenaikan dan penurunan nilai koefisien respon laba. Dan didapatkan angka negatif dalam hubungannya dengan koefisien respon laba, Hubungan negatif mungkin dikarenakan semakin tinggi tingkat keinformatifan harga saham, maka kandungan informasi dan laba akuntansi semakin berkurang. Oleh sebab itulah, koefisien respon laba justru semakin rendah ketika ukuran perusahaan atau keinformatifan harga saham meningkat. Bila dihubungkan dengan reaksi investor mungkin disebabkan oleh optimis investor high risk averse pada kinerja perusahaan kecil saat itu, dimana dengan analisis komprehensif atas nilai perusahaan dan potensi pertumbuhan kecil juga memiliki kemungkinan return positif. Bagi investor yang ingin berinvestasi pada industri barang konsumsi tidak perlu menganalisis ukuran perusahaan, karena respon pasar justru negatif terhadap ukuran perusahaan. Bahkan pelaku pasar masih merespon pada industri dengan ukuran lebih kecil karena pelaku pasar mungkin memiliki pandangan semakin besar ukuran perusahaan semakin besar juga cost operasional perusahaan, dan semakin sulit untuk bagi perusahaan untuk meningkatkan kinerja dan berdampak pada tingkat pengembalian investasi.

Pengujian terhadap pengaruh Default Risk terhadap Koefisien Respon Laba diketahui nilai t hitung sebesar 1,273 dan nilai probabilitas 0,225 $>$ taraf signifikansi 5\% artinya bahwa tidak ada pengaruh Variabel Devault Risk yang diproksi dengan Leverage terhadap koefisien respon laba.. Hasil penelitain ini menunjukkan bahwa tinggi rendahnya default risk tidak berpengaruh terhadap kenaikan dan penurunan nilai koefisien respon laba perusahaan. Hasil ini bertentangan dengan hasil penelitian Dhaliwal dan Reynolds (1994). Pasar tidak terlalu merespon tingkat leverage perusahaan, yang berartijuga menunjukkan bahwa pelaku pasar tidak perduli terhadap utang perusahaan karena investor masih menilai positif perusahaan yang memiliki utang, karena utang juga sangat penting untuk menunjang bisnis perusahaan. Bagi pelaku 
pasar atau pihak investor yang ingin berinvestasi pada industri barang konsumsi masih perlu mempertimbangkan untuk menghitung tingkat $l e-$ verage perusahaan sebagai usaha antisipasi, karena tingkat leverage perusahaan menggambarkan tingkat kemampuan perusahaan dalam mengelola keuangan dan nilai kemampuan aset perusahaan untuk menjamin terbayarnya hutang. Pihak pemerintah juga harus mempertimbangkan tingkat suku bunga bagi industri barang konsumsi, agar bisnis pada industribarang konsumsi tetap bisa hidup dan berkembang, kebijakan-kebijakan fiskal terhadap industri barang konsumsi juga merupakan suatu hal yang seharusnya jadi bahan pertimbangan pemerintah dalam mengambil kebijakan, mengingat industri barang konsumsi merupakan industri yang mampu meningkatkan tarap kehidupan masyarakat. Dan bagi pihak Bapepam sebagai pengawas pasar modal harus sering menilai tingkat tingkat leverage perusahaan, sebagai bahan antisipasi terjadinya likuidasi pada perusahaan yang memiliki leverage yang tinggi.

\section{KESIMPULAN DAN SARAN}

\section{Kesimpulan}

Dari hasil pengujian terhadap faktor-faktor yang mempengaruhi sentivitas laba pada industri barang konsumsi di Indoensia periode tahun 2007 -2010 dengan menggunakan koefisien respon laba sebagai alat ukur sensitivitas laba dan konservatisme laporan keuangan, siklus hidup perusahaan, pertumbuhan laba, rasio pembayaran dividen, ukuran perusahaan dan default risk sebagai variabel independen, dihasilkan hanya dua variabel yang berpengaruh signifikan terhadap sensitivitas laba, yaitu variabel siklus hidup perusahaan dan variabel pertumbuhan laba.

Pemerintah perlu memperhatikan perusahaan yang bergerak pada bidang industri barang konsumsi karena industri barang konsumsi mampu menopang perekonomian negara, produk yang dihasilkan oleh industri barang konsumsi berhubungan dengan kehidupan rakyat Indonesia.
Pihak Bapepam sebagaipengawas pasar modal di Indonesia perlu mempertimbangkan untuk terus mengawasi Industri barang konsumsi bukan hanya tingkat penjualan tapi juga dari aspek lain misalnya produk perusahaan industri konsumsi juga harus mempertimbangkan dampak terhadap kesehatan masyarakat, sehingga industri barang konsumsi yang hanya mengejar tingkat penjualan atau keuntungan, tetapi manfaat produk bagi masyarakat.

Pihak pemerintah juga harus merespon secara positif terhadap perusahaan yang memiliki pertumbuhan laba yang cenderung meningkat karena akan menunjang dan memastikan pajak dari laba akan meningkat, dan Badan pengawas pasar modal harus merespon industri-industriyang memiliki kinerja laba ataupun pertumbuhan laba yang cenderung meningkat agar diberi penghargaan (reward) yang berdampak secara tidak langsung terhadap penilaian masyarakat terhadap penilaian atau persepsi masyarakat terhadap perusahaan yang mendapat penghargaan tersebut.

\section{Keterbatasan}

Keterbatasan dalam penelitian ini yaitu periode penelitian yang relatif pendek, data yang digunakan dalam penelitian ini adalah periode tahun 2007-2010. Mengakibatkan tidak terdapatnya perusahaan pada fase siklus hidup start - up dan decline.

\section{Saran}

Pertimbangan yang diperlukan untuk mengembangkan penelitian ini:

1. Peneliti selanjutnya diharapkan memperpanjang periode amatan penelitiannya sehingga diharapkan dapat memperoleh besaran koefisien respon laba yang lebih baik.

2. Peneliti selanjutnya juga dapat menambah variabel determinan koefisien respon laba, baik dari segi informasi akuntansi atau pun determinan yang berkaitan dengan sektormakro ekonomi. 


\section{DAFTAR PUSTAKA}

Ambarwati, Sri, 2008. Earnings Response Coefficient. Majalah Akuntabilitas Univ. Pancasila. Vol. 7, No. 2 hal $128-134$

Amihud, Y., dan K. Li. 2002. The Declining Information Content of Dividend Announcements and the Effect of Institutional Holdings. Working Paper. econ.em.tsinghua.edu.cn/, (December 2).

Black, E.L. 1998, Life-cycle impacts on the incremental value-relevance of earnings and cash flow measures. The Journal of Financial Statement Analysis, 4: 40-56

Collins, D.W., and S.P.Kothari. 1989. An Analysis of International and Cross-Sectional Determinants ofEarnings Response Coefficients. Journal of Accounting and Economics, pages. 143-181.

Chaney, Paul K. dan Debra C. Jeter. The Effect of Size on The Magnitude of Long Window Earnings Response Coefficients. Contemporary Accounting Research. Vol. 8, No. 2 (1991): 540-560

Dewi, A. A. A. Ratna. 2004. Pengaruh Konservatisma Laporan Keuangan Terhadap Earnings Response Coefficient. Jurnal Riset Akuntansi Indonesia. Vol.7 No. 2, IAI, Hal. 207-223.

Dhaliwal, D.S. dan S.R. Stanley. 1994. The Effect ofDefault Risk of Debt on the Earnings Response Coefficient. The Accounting Review, Vol. 69, No. 2, pages. 412-419.

Febrianto, R. dan E. Widiastuty. 2005. Tiga Angka Laba Akuntansi: Mana yang Lebih Bermakna Bagi Investor. Simposium Nasional Akuntansi VIII, di Solo, Jawa Tengah, Hal $159-171$

Ghozali, I. 2006. Aplikasi Analisis Multivariate dengan program SPSS. Cetakan IV. Badan Penerbit UNDIP.

Gup. B dan, R. Agrrawal. 1996. The Product Life Cycle: AParadigm forUnderstanding. Financial Practive and Education. F111/ Winter: 41-48

Juniarti dan R. Limanjaya. 2005. Mana yang Lebih Memiliki Value Relevant: Net Income atau
Cash Flows (Studi Terhadap Siklus Hidup Organisasi). Jurnal Akuntansi dan Keuangan, Vol. 7, No. 1, Hal. 22-42.

Kothari, S.P. dan R.G. Sloan. 1992. Information in Price About Future Earnings: Implication for Earnings Response Coefficients. Journal of Accounting and Economics Vol. 15, Issues 2 - 3 June-September, Pages 143 - 171

Mayangsari, S. 2004. Bukti Empiris Pengaruh Spesialisasi Industri Auditor Terhadap Earnings Response Coefficien. Jurnal Riset Akuntansi Indonesia, Vol. 7, No. 2, Hal.154-178.

Murhadi, W. R. 2008. Studi Kebijakan Dividen: Anteseden dan Dampaknya Terhadap Harga Saham. Jurnal Manajemen dan Kewirausahaan, Vol. 10, No. 1, Hal. 1-17. Naimah, Z. 2005. Pengaruh Karakteristik Perusahaan Terhadap Koefisien Respon Laba dan Koefisien respon Nilai Buku Ekuitas: Studi Pada Perusahan Manufaktur di Bursa Efek Jakarta. Majalah Ekonomi, Th. XV, No. 3, Hal. 221-243.

Naimah, Z. dan S. Utama. 2006. Pengaruh Ukuran Perusahaan, Pertumbuhan, dan Profitabilitas Perusahaan Terhadap Koefisien Respon Laba dan Koefisien Respon Nilai Buku Ekuitas: Studi Pada Perusahaan Manufaktur di Bursa Efek Jakarta. Simposium Nasional Akuntansi IX, Padang, Hal. 1 - 26.

Setiati, F. dan I.W. Kusuma. 2004. Faktor-Faktor yang Mempengaruhi Koefisien Respon Laba Pada Perusahaan Bertumbuh dan Tidak Bertumbuh. Simposium Nasional Akuntansi VII, di Denpasar, Bali Hal. 1 - 18

Suwardjono. 2005. Teori Akuntansi: Perekayasaan Pelaporan Keuangan.Edisi Ketiga. Yogyakarta: BPFE.

Uyara, A.S. dan Tuasikal A. 2003. Moderasi Aliran Kas Bebas Terhadap Hubungan Rasio Pembayaran Dividen dan Pengeluaran Modal Dengan Earnings Response Coefficient. Jurnal Riset Akuntansi Indonesia Vol. 6 No. 2, Hal. 186-198. 